DOI: 10.20472/IAC.2018.038.018

PALLAVI KISHORE

Middlesex University Dubai, United Arab Emirates

MARIAM ASLAM

Middlesex University Dubai, United Arab Emirates

\title{
EVIDENCE ON THE NATURE AND EXTENT OF FALL IN OIL PRICES ON THE FINANCIAL PERFORMANCE OF LISTED COMPANIES: A RATIO ANALYSIS CASE STUDY OF THE INSURANCE SECTOR IN THE UAE
}

\begin{abstract}
:
The sharp decline in oil prices that started in 2014 affected most economies in the world either positively or negatively. United Arab Emirates has been striving to diversify away from oil and expects higher non-oil growth in 2018. This study involves calculations and comparisons of ratios pre and post the fall in oil prices in the insurance sector in the UAE. Parametric tests, conclude that while the change in profitability and efficiency ratios is statistically significant, the other ratios have been quite stable in the period. There has been an overall slowdown in the insurance industry yet UAE has been mostly resilient to the fall in oil prices and given the visionary leadership of its policy makers, the diversification strategy has taken effect rather quickly.
\end{abstract}

\section{Keywords:}

Insurance Sector, Oil prices, Parametric test, Profitability, Ratio analysis, United Arab Emirates 


\section{Introduction}

The sharp decline in oil prices that started in 2014 affected most economies in the world either positively or negatively. In some economies, particularly the oil exporting countries, the effects were felt immediately.

The Gulf Cooperation Council's (GCC henceforth) countries are oil and gas dependent with the largest oil reserves in the world. According to Organization of the Petroleum Exporting Countries (OPEC henceforth) Annual Statistics Bulletin's 2017 estimates, $81.5 \%$ of the world's proven crude oil reserves are located in OPEC Member Countries, with the bulk of OPEC oil reserves in the GCC, amounting to $65.5 \%$ of the OPEC total by the end of 2017. The GCC's short term economic outlook continues to mirror the diversity across the region. While the global economy has remained dependant on the GCC for its energy needs since the 1970s, fiscal positions in a number of oil exporting countries are weakening because of sharp declines in oil prices from 2014 till date. As a result of this, governments have been forced to explore options that diversify their economies, cut down spending and create new sources of revenue such as Value Added Tax (VAT).

Although, insurance has grown at an impressive rate in the last five years (2012-2017), regional insurance penetration remains lower than in most of the world's emerging markets. According to a report by Ernst \& Young (EY) published in 2017, growth has primarily come from compulsory insurance coverage, that is, third party motor and health insurance. Life insurance and savings have made a negligible contribution, except for the UAE, Iran and Egypt. Commercial lines, that is, property and engineering has shown the worst performance due to poor economic conditions and fading growth in commerce and trade.

Over the short run, the decline in oil prices is the most important factor that affects the GCC region with significant effects on the insurance industry. A fall in oil prices has led to a decline in government spending which in turn has led to in-flight projects being delayed or cancelled and new projects postponed. As a result, government tenders for insurance have become more price driven.

Due to poor economic activity post fall in oil prices, consumers have also become more price sensitive and consider cost as an important buying consideration. This has led to a decline in the sales of optional insurance products such as home and travel insurance. Automobile insurance has also been affected as consumers now prefer to buy third party liability instead of comprehensive coverage.

Insurance penetration in the UAE is now one of the highest in the region, though it is still significantly lower than in most global markets. UAE aims to move toward a service- 
based economy by 2021, with oil contribution to GDP falling from around 30\% in 2016 to 20\% (EY Report, 2017).

There are 31 companies in the insurance sector listed in the Dubai Financial Market (DFM) and the Abu Dhabi Securities Exchange (ADX). This paper analyses the performance of all the listed companies in the insurance sector pre and post fall in oil prices. Financial ratio analysis has been carried out and 11 ratios have been calculated to study the effects of a decline in oil prices and to draw a conclusion about performance of the sector. The financial performance of these companies has been categorised under five groups of ratios namely profitability, efficiency, liquidity, gearing and investment. Parametric test, namely Paired t-test was used to see whether the calculated ratios differ pre and post fall in oil prices. The results show a decline in profitability, liquidity, gearing and investment ratios, and an increase in efficiency ratios.

\section{Importance of the Study}

The reason for analysing the insurance sector is that this sector is widely recognized as an important indicator of the overall health of the economy. An expanding population, surge in construction and infrastructure, increased life expectancy, greater expenditure on automobiles and other luxury goods translate to a booming insurance sector. A slowdown of the insurance sector on the other hand may indicate a general slowdown in the economy. For instance, a failure of the property insurance market signifies individuals lose confidence in buying properties; a slowdown in business insurance market signifies loss in business investment. These might have a ripple effect on the health of the economy and therefore, a study of the insurance sector will help understand the state of the economy.

In 2017, Alpen Capital, a leading investment banking advisory in the UAE, estimated that the insurance industry in UAE, Oman and Saudi Arabia is expected to grow at an average growth rate (of $12.1 \%$ and UAE will continue to dominate the insurance market in the region with a market size expanding to $\$ 18.1$ billion by 2021 . This growth will be driven by large project developments ahead of Expo 2020 with premiums arising from property insurance.

UAE has remained dependent on oil for its economic growth. However, the recent decline in oil prices has forced the government to move away from traditional oil revenues.

There are a few reasons that act as motivations behind this research. First, although there is a general decline in oil prices, there has been no empirical evidence or a comprehensive study conducted in UAE to prove the same. Second, Ernst \& Young has stressed the necessity of more research on this sector to understand the health of an 
economy. Third, this study, to the best of our knowledge makes an original contribution to the body of research as it analyses the financial performance of thirty one major UAE insurance companies which have passed through the period of falling oil prices. Lastly, due to the volatile nature of these companies performance lately in the region, this study will provide a better understanding of the performance fluctuations in insurance companies pre and post fall in oil prices.

\section{Literature Review}

\section{Impact of Oil Price Movements}

Given the significant role of crude oil in the economy, fluctuations in oil prices have received much attention from research scholars. Impact of oil prices on financial performance of firms is an actively growing area of research. Research has been conducted examining the relationship between crude oil prices with various other factors. Dayanandan and Donker (2011) examined the relationship between commodity prices of crude oil, capital structure, firm size and accounting measures of firm performance using a sample of oil and gas firms in North America from 1990 to 2008. Their study found that crude oil prices had a positive and significant impact on accounting returns (Return on Equity) of oil and gas firms in North America. Their study also revealed that the financial crisis of 2007-2008 had a negative impact on oil prices and the accounting performance of these firms. On the other hand, the Asian financial crisis and 9/11 did not have any significant effect on the performance of oil and gas companies. Sadrosky (2008) examined the relationship between oil price movements, firm size and stock prices. The study analysed a panel of firms over a 17 year period. The empirical results of this study show that the relationship between oil price movements and stock returns does vary depending on the size of the firm and medium sized firms are more likely to be negatively affected in terms of stock prices, by oil price movements.

Wattanatorn and Kanchanapoom (2012) on the other hand, investigated the impact of crude oil prices on the profitability performance of sector using data on companies listed on the stock exchange of Thailand from 2001-2010 using the method of panel data regression. Their study found that the oil prices have a significant impact on the profits of firms in energy and food sectors.

Considerable research has been done to analyse the impact of oil prices on firm and equity returns. One such study was conducted by Narayan and Sharma (2011) that examined the relationship between oil price and firm returns for 560 firms listed on the New York Stock Exchange (NYSE). The results of their study show that the effect of oil prices on firm returns varied depending on the sector to which firms belong to. Their findings suggest that the firms in energy and transportation sectors witness a rise in 
returns when oil prices rise. On the other hand, the firms in other sectors witness a fall in returns when oil prices fall implying a heterogeneous effect on firm returns. Nandha and Faaf (2008) also looked at the same issue that is, relationship between oil price and equity prices by analysing 35 DataStream global industry indices from April 1983 to September 2005. Their findings suggest that oil prices have a negative impact on equity returns for all sectors except mining and oil and gas sectors. The authors asserted that their findings were consistent with economic theory and evidence provided by previous empirical studies. Similarly, El Sharif et al (2005) investigated the relationship between the price of crude oil and equity values in the oil and gas sector using data for companies in the United Kingdom (UK). The findings suggest that relationship is always positive and highly significant and reflects the direct impact of volatility in the price of crude oil on share values within the sector.

Studies have also been conducted on the relationship between crude oil prices and stock markets in GCC. A study conducted by Maghyereh and Al-Kandari (2007) examined the linkages between oil prices and stock markets in GCC countries. Their findings suggest that oil prices impact the stock price indices in GCC countries in a nonlinear fashion.

A number of studies looked at how oil prices affect macroeconomic variables. A study by Kilian (2008) investigates the impact of exogenous oil supply shock on the United States (US) economy. The findings suggest a spike in Consumer Price Index (CPI) inflation three quarters after the exogenous oil supply shock rather than a sustained increase in inflation. The results also suggest that exogenous oil shocks made remarkably little difference overall for the evolutions of US real GDP growth and CPI inflation since the 1970s, although they did matter for some historical periods. Ewing et al (2007) investigated the empirical relationship between oil prices and a number of key macroeconomic variables. Their study examined the cyclical co movements of crude oil prices with output, consumer prices, unemployment and stock prices and their findings suggest that crude oil prices are pro cyclical and lag industrial productions. In addition to this, the results of the study show that oil prices lead consumer prices. Berument et al (2010) analysed the effects of oil price shocks on the output growth of 16 countries in Middle East and North African (MENA) region that are considered either net exporters or net importers on crude oil, but are too small to have any influence on oil prices. The findings of this study suggest that increases in oil price have a significant and positive impact on the growth of most of the oil-exporting economies.

\section{Insurance Industry}

Insurance sector is an important part of the financial system in any economy. Financial sustainability of insurance firms is key to foster economic growth. Studies on the insurance sector are limited most of them focus on the factors that influence the financial performance of insurance companies. In general, most of the past studies suggest that 
firm size is a key determining factor that influence profitability. For example, Chen-Ying (2014), Burca and Ghiorghe (2014) and Malik (2011) examined the effects of firm specific factors and concluded that there is a positive relationship between firm size and profitability in terms of Return on Assets of insurance firms. Along with firm size, the degree of leverage has also been identified by several researchers like Dogan (2013), Al Shami (2008), Omondi and Muturi (2013), Onaolapo and Sunday (2010), Athanasoglou et al., (2008) and Adams and Buckle (2003), as having a negative impact on the financial performance of insurance companies.

\section{Data and Methodology}

The study includes data from listed insurance companies in UAE. Abu Dhabi Exchange (ADX) lists 17 companies in the insurance sector, while Dubai Financial Markets (DFM) lists another 14. Financial data from 31 companies was corroborated from audited financial statements for the period 2013, 2014 (pre-fall) and 2015, 2016 (post-fall). The performance of companies during these periods was studied using Financial Ratio Analysis.

Ratio analysis has been one of the most widely used methods in measuring financial performance. Al-Malkawi \& Pillai (2010); Beyer (2010) and Downs \& Goodman (2003) have strongly supported the methodology suggesting that financial health of companies can be measured by quantitative analysis and ratios can be used to make yearly comparisons to determine industry trend. Following literature, 11 ratios have been calculated to better understand the Profitability, Efficiency, Liquidity, Gearing and Investment performance during the pre- and post-fall in oil prices.

Performance of the insurance sector gives an impression of the overall economy. A strong construction sector gives impetus to the non-life insurance segment while economically progressive population gives an impetus to the medical, automobile and other compulsory insurance segments. In order to understand if the performance of the insurance sector changed significantly, pre- and post-fall in oil prices, the data was divided into two cohorts, depicting the two periods. Formal statistical tests, including parametric tests were conducted; paired t-test was used to see if the figures in the two periods differ significantly. The sample size (62 pairs) allows us to use parametric test, which is more reliable and accurate as compared to its alternative non-parametric test, the Wilcoxon matched pairs test. Furthermore, in this case, since the values are normally distributed and mean values are statistically more accurate than median, deeming the use of t-test feasible. 
The null and alternate hypothesis to be tested are stated as follows:

$H_{0}$ : There is no change in the population mean (for a particular ratio) pre- and post-fall in oil prices.

$H_{1}$ : There is a change in the population mean (for a particular ratio) pre- and post-fall in oil prices.

\section{Findings and Discussion}

Financial Ratios in the categories Profitability, Efficiency, Liquidity, Gearing and Investment have been calculated to understand the performance of the insurance sector in the UAE pre- and post-fall in oil prices. The sample size of 62 shows 2 years' worth of data for the 31 insurance companies. The 11 ratios will help understand which of these categories (if any) were most affected by the fall in oil prices. This information can be critical for the government in setting policies and regulations that will enable financial wellbeing and overall growth of the economy. Individual companies can also use the findings of this study to understand which part of their business needs more attention and perhaps corrective action.

\section{Profitability Ratios}

Profitability ratios are used to assess the ability of a business to generate earnings. An increase in profitability ratios would indicate financial wellbeing of the company/ industry. The three ratios calculated explain the returns to shareholder funds, return on capital employed and net profit margin. These ratios will shed light on the sales generated, costs incurred and owners' equity.

\begin{tabular}{|c|c|c|c|c|c|}
\hline \multicolumn{5}{|c|}{ Profitability Ratios: Paired Samples Statistics } \\
\hline \multirow{2}{*}{} & Mean & N & $\begin{array}{c}\text { Std. } \\
\text { Deviation }\end{array}$ & $\begin{array}{c}\text { Std. Error } \\
\text { Mean }\end{array}$ \\
\hline \multirow{2}{*}{ Pair 1 } & ROSF & 0.0329 & 62 & 0.15740 & 0.01999 \\
\cline { 2 - 6 } & PostROSF & -0.5715 & 62 & 4.48093 & 0.56908 \\
\hline \multirow{2}{*}{ Pair 2 } & ROCE & 0.0218 & 62 & 0.06050 & 0.00768 \\
\cline { 2 - 6 } & PostROCE & 0.0016 & 62 & 0.05109 & 0.00649 \\
\hline \multirow{2}{*}{ Pair 3 } & NPM & 0.1887 & 62 & 0.90488 & 0.11492 \\
\cline { 2 - 6 } & PostNPM & 0.0358 & 62 & 0.27120 & 0.03444 \\
\hline
\end{tabular}

Table 1.1 Profitability Ratios Preliminary Analysis 
Table 1.1 above summarizes the profitability ratios, clearly indicating a decrease in all values. The increase in standard deviation indicates higher volatility in the post-fall period.

\begin{tabular}{|c|c|c|c|c|}
\hline \multicolumn{5}{|c|}{ Profitability Ratios: Paired Samples Correlations } \\
\hline \multicolumn{2}{|c|}{} & N & Correlation & Sig. \\
\hline Pair 1 & ROSF \& PostROSF & 62 & -0.011 & 0.933 \\
\hline Pair 2 & ROCE \& PostROCE & 62 & 0.320 & 0.011 \\
\hline Pair 3 & NPM \& PostNPM & 62 & 0.508 & 0.000 \\
\hline
\end{tabular}

Table 1.2 Profitability Ratios Paired Correlations

Table 1.2 confirms low correlation in the profitability ratios, namely Return on Shareholder Funds, Return on Capital Employed and Net Profit Margin. This is in-line with our initial expectation; the ratios are calculated using profits and revenues which are period figures, i.e. they start with a zero balance and represent performance in a single time period alone.

\begin{tabular}{|c|c|c|c|c|c|c|c|c|c|}
\hline \multicolumn{10}{|c|}{ Profitability Ratios: Paired Samples Test } \\
\hline & & \multicolumn{5}{|c|}{ Paired Differences } & \multirow{3}{*}{$t$} & \multirow{3}{*}{ df } & \multirow{3}{*}{$\begin{array}{c}\text { Sig. } \\
(2- \\
\text { tailed } \\
\quad)\end{array}$} \\
\hline & & \multirow[t]{2}{*}{ Mean } & \multirow[t]{2}{*}{$\begin{array}{c}\text { Std. } \\
\text { Deviatio } \\
n\end{array}$} & \multirow[t]{2}{*}{$\begin{array}{l}\text { Std. } \\
\text { Error } \\
\text { Mean }\end{array}$} & \multicolumn{2}{|c|}{$\begin{array}{c}95 \% \\
\text { Confidence } \\
\text { Interval of the } \\
\text { Difference }\end{array}$} & & & \\
\hline & & & & & Lower & $\begin{array}{c}\text { Uppe } \\
r\end{array}$ & & & \\
\hline Pair 1 & $\begin{array}{c}\text { ROSF - } \\
\text { PostROSF }\end{array}$ & 0.60435 & 4.48541 & 0.56965 & $\begin{array}{c}- \\
0.534 \\
73\end{array}$ & $\begin{array}{c}1.743 \\
44\end{array}$ & 1.061 & 61 & 0.293 \\
\hline Pair 2 & $\begin{array}{c}\text { ROCE - } \\
\text { PostROCE }\end{array}$ & 0.02016 & 0.06550 & 0.00832 & $\begin{array}{c}0.003 \\
53\end{array}$ & $\begin{array}{c}0.036 \\
79 \\
\end{array}$ & $2.424^{\star \star}$ & 61 & 0.018 \\
\hline Pair 3 & $\begin{array}{c}\text { NPM - } \\
\text { PostNPM }\end{array}$ & 0.15290 & 0.80179 & 0.10183 & $\begin{array}{c}- \\
0.050 \\
71\end{array}$ & $\begin{array}{c}0.356 \\
52\end{array}$ & 1.502 & 61 & 0.138 \\
\hline & & tinolls & ficant at & $0 \%,{ }^{* *} 5 \%$ & ***1 pe & ent leve & & & \\
\hline
\end{tabular}

Table 1.3 Profitability Ratios Advanced Analysis

ROSF, also known as Return on Equity is calculated by dividing the net income by Shareholders' Equity. It depicts the amount of profits generated by use of shareholder 
investments. The figure also showcases the amount of funds available to shareholders after all costs of running the business (including debt costs) have been met. This is an important ratio as it indicates how effectively and efficiently the company resources are being utilized to generate profits.

Table 1.1 shows that ROSF fell from 0.0329 in pre-fall to -0.5715 in the post-fall period. It can be noted that the returns weren't high in the pre-fall period either (3.3\%), however, in the post-fall period, a negative figure is dangerous and signifies loss. T-Statistics in Table 1.3 confirms that the difference however is not significant. The null hypothesis cannot be rejected due to the high $p$-value. It can be said that the fall in oil prices has not had a significant change in the ROSF.

As a general rule of thumb, ROSF above $20 \%$ is considered a good investment option, while below $10 \%$ is not considered safe (Dorsey 2003). Given our figures and the importance of this ratio, the outlook for the insurance industry does not seem positive.

$R O C E$ is calculated by dividing the operating profits by the two aspects of capital raised, namely, noncurrent liabilities and owners' equity; thereby showing the amount of profit generated for each dirham invested. This is the most important ratio, as it is used to comment on the profitability and effectiveness with which the company uses its employed capital.

Table 1.1 shows that ROCE fell from 0.0218 in pre-fall to 0.0016 in the post-fall period. It must be stated that the profitability itself in the first place was small $(2.2 \%)$ and then nose-dived to a mere $0.16 \%$. Table 1.3 confirms that the difference is statistically significant at a $5 \%$ level and easily reject the null hypothesis. It is clear that fall in oil prices had an adverse effect on the profitability of companies in the insurance sector in the UAE. Further analysis of the two components involved in the aforementioned calculation, namely, operating profit and capital raised, show that average profits fell sharply from AED 34 million pre-fall to AED 13 million post-fall (62\%); while the change in the capital employed has not been as drastic (1.2 trillion to 1.4 trillion: $17 \%$ ).

As a general rule of thumb, the ROCE should be higher than the companies cost of borrowing, else loss is eminent. A decline in ROCE generally is seen as a warning sign, although in this case, the drop is solely due to the fall in profits, attributed to falling oil prices. If the capital figure had also changed substantially, a point could be drawn towards the managerial efficiency, however, this is not the case. 
NPM is calculated by dividing net profit by sales. It discloses the amount of profit each dirham of revenue generates. This ratio is used to gauge the level of efficiency with which a company is managed and is also a good tool to forecast future profitability. Generally speaking, a higher margin is considered better than a lower one since it directly translates to profitability.

Table 1.1 shows that NPM has fallen from 0.1887 in pre-fall to 0.0358 in the post-fall period. The decrease can be attributed to the sharp fall in profits in the insurance sector. T-test in Table 1.3 however does not show a statistically significant difference in the ratio in the two periods. Therefore, the null cannot be rejected and it can be said that the NPM has not changed significantly post-fall in oil prices.

All the profitability parameters have shown a substantial drop in values as oil prices fell between 2013-2016. This is consistent with the findings of the studies conducted by Lele (2016), Basha (2014), Sadrosky (2008), El-Sharif et al (2005) and Malik et al (2009). However, in our findings only ROCE values pre and post fall in oil prices are statistically significant. The correlation figures for ROSF and NPM are negative but not statistically significant.

\section{Efficiency Ratios}

Efficiency ratios are used to gauge how efficiently the assets and receivables are being managed by the firm. An increase or decrease in efficiency ratios must be treated with caution as it may not necessarily have the desired impact on company performance. The two ratios calculated explain the asset turnover and the receivable days for the insurance sector.

\begin{tabular}{|c|c|c|c|c|c|}
\hline \multicolumn{6}{|c|}{ Efficiency Ratios: Paired Samples Statistics } \\
\hline & Mean & N & Std. Deviation & $\begin{array}{c}\text { Std. Error } \\
\text { Mean }\end{array}$ \\
\hline \multirow{2}{*}{ Pair 4 } & AssetTO & .2395 & 62 & .14159 & .01798 \\
\cline { 2 - 6 } & PostAssetTO & .2502 & 62 & .14895 & .01892 \\
\hline \multirow{2}{*}{ Pair 5 } & SettRec & 342.6224 & 62 & 367.24915 & 46.64069 \\
\cline { 2 - 6 } & PostSettRec & 240.8315 & 62 & 130.35077 & 16.55456 \\
\hline
\end{tabular}

Table 2.1 Efficiency Ratios Preliminary Analysis

Table 2.1 above summarizes the efficiency ratios, indicating a slight increase in asset turnover with a stable standard deviation. The receivable settlement period however decreased in the post-fall in oil prices period. The standard deviation is quite high before 
the fall in oil prices indicating extreme volatility, however, the decrease in standard deviation post-fall in oil prices indicates that credit was not extended as comfortably in this period, depicting lack of trust in the markets.

\begin{tabular}{|c|c|c|c|c|}
\hline \multicolumn{5}{|c|}{ Efficiency Ratios: Paired Samples Correlations } \\
\hline \multicolumn{2}{|c|}{} & $\mathbf{N}$ & Correlation & Sig. \\
\hline Pair 4 & AssetTO \& PostAssetTO & 62 & .801 & .000 \\
\hline Pair 5 & SettRec \& PostSettRec & 62 & .247 & .053 \\
\hline
\end{tabular}

Table 2.2 Efficiency Ratios Paired Correlations

Table 2.2 above shows a high correlation for the asset turnover, as expected, since the non-current assets continue to be the same in both the periods. However, receivable settlement period shows a low correlation since the ratio uses period figures namely, receivables and credit sales.

\begin{tabular}{|c|c|c|c|c|c|c|c|c|c|}
\hline \multicolumn{10}{|c|}{ Efficiency Ratios: Paired Samples Test } \\
\hline & & \multicolumn{5}{|c|}{ Paired Differences } & \multirow{3}{*}{$\mathbf{t}$} & \multirow{3}{*}{ df } & \multirow{3}{*}{$\begin{array}{l}\text { Sig. (2- } \\
\text { tailed) }\end{array}$} \\
\hline & & \multirow[t]{2}{*}{ Mean } & \multirow{2}{*}{$\begin{array}{l}\text { Std. } \\
\text { Deviati } \\
\text { on }\end{array}$} & \multirow{2}{*}{$\begin{array}{l}\text { Std. } \\
\text { Error } \\
\text { Mean }\end{array}$} & \multicolumn{2}{|c|}{$\begin{array}{c}95 \% \text { Confidence } \\
\text { Interval of the } \\
\text { Difference }\end{array}$} & & & \\
\hline & & & & & Lower & Upper & & & \\
\hline $\begin{array}{c}\text { Pair } \\
4\end{array}$ & $\begin{array}{c}\text { AssetTO - } \\
\text { PostAssetTO }\end{array}$ & $\begin{array}{c}- \\
.0106 \\
5\end{array}$ & .09197 & .01168 & -.03400 & .01271 & -.911 & 61 & 366 \\
\hline $\begin{array}{l}\text { Pair } \\
5\end{array}$ & $\begin{array}{c}\text { SettRec - } \\
\text { PostSettRec }\end{array}$ & $\begin{array}{l}101.7 \\
9097\end{array}$ & $\begin{array}{c}358.13 \\
310\end{array}$ & $\begin{array}{c}45.4829 \\
5\end{array}$ & $\begin{array}{c}10.8421 \\
9\end{array}$ & \begin{tabular}{|c|}
192.739 \\
74
\end{tabular} & $\begin{array}{c}2.23 \\
8\end{array}$ & 61 & .029 \\
\hline
\end{tabular}

Table 2.3 Efficiency Ratios Advanced Analysis

AssetTO, better known as Asset Turnover is calculated by dividing sales by non-current assets. It shows how efficiently the non-current assets are being used to generate business. A high ratio is not necessarily desirable since it may only represent high sales, and not high profits.

Table 2.1 shows that the increase in the ratio is only marginal. Therefore, this ratio doesn't seem to be affected by the fall in oil prices. Furthermore, the t-Statistic confirms that the slight change is not statistically significant. The null hypothesis cannot be rejected due to the high $p$-value and thus it can be confirmed that the fall in oil prices did not have an impact on AssetTO. 
SettRec, representing settlement period for receivables is calculated by dividing receivables by credit sales and multiplying by 365 to convert to days. The ratio shows how long it takes for a debtor to make the payment following a credit sale.

Table 2.1 shows that the average settlement period dropped from 340 days to 240 days. This perhaps indicates that the market confidence took a hit due to fall in oil prices. The fall is statistically significant at $5 \%$ level and easily rejects the null hypothesis. It is clear that the fall in oil prices had an effect on the settlement days, the effect however was positive, as it led to early collection of dues from debtors. Despite a positive change, the outlook seems negative. Comparison with earlier studies is not possible due to lack of similar studies done on this category of ratios.

\section{Liquidity Ratios}

Liquidity ratios are used to confirm that the business is liquid and a going concern. Stable liquidity ensures that the business has and will continue to have enough liquid assets to meet their current obligations. This category of ratios is crucial for banks and other creditors as it helps them to know how quickly their debts can be repaid using short term assets. Two ratios were calculated, namely, Current Ratio and Operating Cashflows. These ratios will help understand if the business needs to make arrangements for short term finance or if enough cash is being generated with the main business operations.

\begin{tabular}{|c|c|c|c|c|c|}
\hline \multicolumn{5}{|c|}{ Liquidity Ratios: Paired Samples Statistics } \\
\hline \multirow{2}{*}{} & Mean & N & Std. Deviation & $\begin{array}{c}\text { Std. Error } \\
\text { Mean }\end{array}$ \\
\hline \multirow{2}{*}{ Pair 6 } & CR & 1.5143 & 7 & .55362 & .20925 \\
\cline { 2 - 6 } & PostCR & 1.4957 & 7 & .55503 & .20978 \\
\hline \multirow{2}{*}{ Pair 7 } & OpCF & .1891 & 56 & .54913 & .07338 \\
\cline { 2 - 6 } & PostOpCF & .3066 & 56 & .92259 & .12329 \\
\hline
\end{tabular}

Table 3.1 Liquidity Ratios Preliminary Analysis

Table 3.1 summarizes the liquidity ratios, showing that while current ratio has been quite stable, the operating cashflow ratio, although small, has increased in the post-fall period.

\begin{tabular}{|c|c|c|c|c|}
\hline \multicolumn{5}{|c|}{ Liquidity Ratios: Paired Samples Correlations } \\
\hline \multicolumn{2}{|c|}{} & $\mathbf{N}$ & Correlation & Sig. \\
\hline Pair 6 & CR \& PostCR & 7 & .934 & .002 \\
\hline Pair 7 & OpCF \& PostOpCF & 56 & .539 & .000 \\
\hline
\end{tabular}




\section{Table 3.2 Liquidity Ratios Paired Correlations}

Table 3.2 shows high correlation for current ratio. This is against initial expectation as it shows that the current assets and liabilities in the post-fall period depend on the ratios in the pre-fall periods. The operating cashflows ratio however shows weak correlation in the two periods, as expected.

\begin{tabular}{|c|c|c|c|c|c|c|c|c|c|}
\hline \multicolumn{10}{|c|}{ Liquidity Ratios: Paired Samples Test } \\
\hline & & \multicolumn{5}{|c|}{ Paired Differences } & \multirow{3}{*}{$\mathbf{t}$} & \multirow{3}{*}{ df } & \multirow{3}{*}{$\begin{array}{l}\text { Sig. (2- } \\
\text { tailed) }\end{array}$} \\
\hline & & \multirow[t]{2}{*}{ Mean } & \multirow[t]{2}{*}{$\begin{array}{l}\text { Std. } \\
\text { Deviati } \\
\text { on }\end{array}$} & \multirow[t]{2}{*}{$\begin{array}{l}\text { Std. } \\
\text { Error } \\
\text { Mean }\end{array}$} & \multicolumn{2}{|c|}{$\begin{array}{c}95 \% \\
\text { Confidence } \\
\text { Interval of the } \\
\text { Difference }\end{array}$} & & & \\
\hline & & & & & Lower & Upper & & & \\
\hline Pair 6 & $\begin{array}{c}\text { CR - } \\
\text { PostCR }\end{array}$ & $\begin{array}{c}.0185 \\
7\end{array}$ & .20186 & .07630 & -.16812 & .20526 & .243 & 6 & .816 \\
\hline Pair 7 & $\begin{array}{c}\text { OpCF - } \\
\text { PostOpCF }\end{array}$ & $\begin{array}{c}- \\
.1175 \\
0\end{array}$ & .77866 & .10405 & -.32603 & .09103 & $\begin{array}{c}- \\
1.12 \\
9\end{array}$ & 55 & .264 \\
\hline
\end{tabular}

Table 3.3 Liquidity Ratios Advanced Analysis

$C R$, the Current Ratio is a simple ratio between the current assets and current liabilities. The ratio shows if the business is making enough current assets to cover their current liabilities. As a rule of thumb, the ratio should be 2, i.e. the current assets should be double the current liabilities, just in case they are not all converted to cash as the liabilities become due.

Table 3.1 shows that ratio has been around 1.5 in both the periods of study. The ratio is fair and represents stability. The t-statistic confirms that the difference is not statistically significant and hence unaffected by the fall in oil prices.

OpCF represents the Operating Cash Flows and is calculated by dividing the cashflows from operations by the current liabilities. A higher figure would show that the cash generated by operations is large and would be a positive sign for the industry.

Table 3.1 shows that the ratio has increased from 0.19 to 0.31 , however the increase is not statistically significant, hence we cannot reject the null hypothesis. This confirms that both the liquidity ratios were not affected by the fall in oil prices. The increase however was expected, given the credit days were reduced, the focus in the post-fall period has been on cash sales rather than credit sales. 


\section{Gearing Ratios}

Gearing ratios are used to keep a balance between the funds raised by issuing shares and that by taking a loan. The gearing ratios help understand the balance between the two modes of raising finance. While loan financing maybe a cheaper option, it exposes the business to several risks. A single ratio has been calculated in this category.

\begin{tabular}{|c|c|c|c|c|c|}
\hline \multicolumn{6}{|c|}{ Gearing Ratios: Paired Samples Statistics } \\
\hline & Mean & N & Std. Deviation & $\begin{array}{c}\text { Std. Error } \\
\text { Mean }\end{array}$ \\
\hline \multirow{2}{*}{ Pair 8 } & Gearing & .0311 & 62 & .11722 & .01489 \\
\cline { 2 - 6 } & PostGearing & .0265 & 62 & .09374 & .01191 \\
\hline
\end{tabular}

Table 4.1 Gearing Ratios Preliminary Analysis

Gearing Ratios: Paired Samples Correlations

\begin{tabular}{|l|c|c|c|c|}
\hline \multicolumn{2}{|l|}{} & N & Correlation & Sig. \\
\hline Pair 8 & Gearing \& PostGearing & 62 & .118 & .359 \\
\hline
\end{tabular}

Table 4.2 Gearing Ratios Paired Correlations

Table 4.1 above summarizes the gearing ratio, indicating a marginal decrease in the gearing with very low standard deviation in both periods. Additionally, Table 4.2 confirms very low levels of correlation in the gearing in the two periods. Both these facts point towards stability in the business.

\begin{tabular}{|c|c|c|c|c|c|c|c|c|c|}
\hline \multicolumn{10}{|c|}{ Gearing Ratios: Paired Samples Test } \\
\hline & & \multicolumn{5}{|c|}{ Paired Differences } & \multirow{3}{*}{$\mathbf{t}$} & \multirow{3}{*}{ df } & \multirow{3}{*}{$\begin{array}{l}\text { Sig. } \\
(2- \\
\text { tailed) }\end{array}$} \\
\hline & & \multirow[t]{2}{*}{ Mean } & \multirow[t]{2}{*}{$\begin{array}{l}\text { Std. } \\
\text { Deviati } \\
\text { on }\end{array}$} & \multirow[t]{2}{*}{$\begin{array}{l}\text { Std. } \\
\text { Error } \\
\text { Mean }\end{array}$} & \multicolumn{2}{|c|}{$\begin{array}{c}95 \% \\
\text { Confidence } \\
\text { Interval of the } \\
\text { Difference }\end{array}$} & & & \\
\hline & & & & & Lower & Upper & & & \\
\hline $\begin{array}{c}\text { Pair } \\
8\end{array}$ & $\begin{array}{c}\text { Gearing - } \\
\text { PostGearing }\end{array}$ & $\begin{array}{c}.0046 \\
8 \\
\end{array}$ & .14116 & .01793 & -.03117 & .04053 & .261 & 61 & .795 \\
\hline
\end{tabular}

Table 4.3 Gearing Ratios Advanced Analysis

Gearing, is seen as the proportion of non-current liabilities from the total pool of funds raised. This is achieved by dividing the Non-Current Liabilities by the sum of Non-Current Liabilities and the Shareholders' Equity. It assists in understanding the proportion of funds that are borrowed. These funds come at a cost i.e. interest and the business must make sufficient profits in order to meet these requirements. It may not be straightforward to say 
that a number is high since the number fluctuates depending on the nature of the industry. Due to low infrastructural cost and insurance being a service industry, the gearing ratio is not expected to be large. It is interesting to note that while the non-current liabilities have increased (pointing towards an increase in loans in the industry); the gearing has gone down. One possible explanation for this movement is that the shareholder funds have increased post-fall in oil prices. It has been confirmed previously that the Shareholders' Equity has marginally increased in this period, given additional retained profits towards Shareholders' Equity.

The t-statistic in table 4.3 confirms that the fall in gearing is not statistically significant. The null cannot be rejected due to the high $p$-value. It can be said that the fall in oil prices has not had a significant change in the gearing.

\section{Investment Ratios}

Investment Ratios are used to assess returns to shareholders. Preference towards a high or low ratio would generally depend on the nature of investors. A long term investor may not be looking for high dividends while capital gains maybe their primary motive. The three ratios calculated in this category explain the dividends per share, dividend payout and the earnings per share.

\begin{tabular}{|c|c|c|c|c|c|}
\hline \multicolumn{6}{|c|}{ Investment Ratios: Paired Samples Statistics } \\
\hline \multirow{2}{*}{ Pair 9 } & Mean & N & Std. Deviation & $\begin{array}{c}\text { Std. Error } \\
\text { Mean }\end{array}$ \\
\cline { 2 - 6 } & DPS & 1.6674 & 62 & 4.93168 & .62632 \\
\hline \multirow{2}{*}{ Pair 10 } & PostDPS & 1.7889 & 62 & 5.72583 & .72718 \\
\cline { 2 - 6 } & DivPayout & .3465 & 62 & .53485 & .06793 \\
\hline \multirow{2}{*}{ Pair 11 } & PostDivPayout & .2982 & 62 & .57229 & .07268 \\
\cline { 2 - 6 } & EPS & 4.1123 & 62 & 12.80483 & 1.62622 \\
\hline
\end{tabular}

Table 5.1 Investment Ratios Preliminary Analysis

Table 5.1 above summarizes the investment ratios, indicating that while dividend per share increased slightly in the post-fall period, while dividend payout and earnings per share decreased. High fluctuations and volatility are seen in the ratios as attributed by very high standard deviations. 


\begin{tabular}{|c|c|c|c|c|}
\hline \multicolumn{5}{|c|}{ Investment Ratios: Paired Samples Correlations } \\
\hline \multicolumn{2}{|c|}{} & N & Correlation & Sig. \\
\hline Pair 9 & DPS \& PostDPS & 62 & .960 & .000 \\
\hline Pair 10 & DivPayout \& PostDivPayout & 62 & .079 & .542 \\
\hline Pair 11 & EPS \& PostEPS & 62 & .990 & .000 \\
\hline
\end{tabular}

Table 5.2 Investment Ratios Paired Correlations

Table 5.2 above shows high correlation for Dividend per Share (DPS) and Earnings per share (EPS) as per our initial expectation. The ratios use dividend and earnings which are period figures, yet companies follow a dividend policy and hence the figures in any year would be in tandem with those of the previous year. For most companies, the number of shares has remained the same.

\begin{tabular}{|c|c|c|c|c|c|c|c|c|c|}
\hline \multicolumn{10}{|c|}{ Investment Ratios: Paired Samples Test } \\
\hline & & \multicolumn{5}{|c|}{$\begin{array}{l}\text { Paired Differences } \\
\end{array}$} & \multirow{3}{*}{$t$} & \multirow{3}{*}{ df } & \multirow{3}{*}{$\begin{array}{l}\text { Sig. (2- } \\
\text { tailed) }\end{array}$} \\
\hline & & \multirow[t]{2}{*}{ Mean } & \multirow{2}{*}{$\begin{array}{l}\text { Std. } \\
\text { Deviati } \\
\text { on }\end{array}$} & \multirow{2}{*}{$\begin{array}{l}\text { Std. } \\
\text { Error } \\
\text { Mean }\end{array}$} & \multicolumn{2}{|c|}{$\begin{array}{l}\text { 95\% Confidence } \\
\text { Interval of the } \\
\text { Difference }\end{array}$} & & & \\
\hline & & & & & Lower & Upper & & & \\
\hline Pair 9 & $\begin{array}{c}\text { DPS - } \\
\text { PostDPS }\end{array}$ & $\begin{array}{c}- \\
.1214 \\
5\end{array}$ & $\begin{array}{c}1.7051 \\
7\end{array}$ & .21656 & -.55448 & .31158 & -.561 & 61 & .577 \\
\hline $\begin{array}{l}\text { Pair } \\
10\end{array}$ & $\begin{array}{c}\text { DivPayout - } \\
\text { PostDivPay } \\
\text { out }\end{array}$ & $\begin{array}{c}.0482 \\
3\end{array}$ & .75181 & 09548 & -.14270 & 23915 & .505 & 61 & .615 \\
\hline $\begin{array}{c}\text { Pair } \\
11\end{array}$ & $\begin{array}{c}\text { EPS - } \\
\text { PostEPS }\end{array}$ & $\begin{array}{c}.1362 \\
9\end{array}$ & $\begin{array}{c}1.8821 \\
8\end{array}$ & .23904 & -.34169 & .61427 & .570 & 61 & .571 \\
\hline
\end{tabular}

Table 5.3 Investment Ratios Advanced Analysis

DPS, also known as Dividend per Share is calculated by dividing the dividends declared by the number of shares in issue. A higher value would mean higher amount of dividend when the number of shares remains unchanged. This maybe an important ratio for an investor to calculate their returns.

Table 5.1 shows that the ratio increased from 1.6674 to 1.7889 AED per share, which would point towards higher dividends. This is surprising given the general fall in profitability. The high standard deviation shows that there is variability within the industry while some companies may have given higher dividends, other companies may not have 
followed suit. T-statistic in Table 5.3 confirms that the change is not statistically significant.

DivPayout, also known as Dividend Payout Ratio is calculated by dividing dividends declared by the earnings for the year. The figure represents the proportion of earnings given out as dividend. As before, preference for higher or lower dividend payout depends on investor attitude. The table above shows that the dividend payout has decreased in the post-fall period while the pre- and post-figures have very low correlation. Although higher total dividends are being paid, the earnings have been lower in the post-fall period and hence a fall in dividend payout is imminent. The fall in dividend payout however is not statistically significant.

EPS, also known as Earnings per Share is calculated by dividing the earnings available to ordinary shareholders by the number of shares in issue. This is one of the most important investment ratios as it represents the profit attributable to each share. Larger the figure, better the financial performance of the company. Table 5.1 shows that the EPS has gone down in the post-fall period while Table 5.3 confirms that the change is not statistically significant. This was rather expected, due to lower earnings in the post-fall period. The correlation is high, as per initial expectation. The standard deviation is rather high, indicating great variability in the earnings across businesses in the industry. The null hypothesis cannot be rejected due to high $p$-value. It can be said that the fall in oil prices did not have a significant effect on any of the investment ratios.

\section{Conclusion and Recommendations}

UAE has been a major provider of oil resources and has had a heavily oil-dependent economy in the recent past. Much debate and high uncertainty surround economic decisions ever since the oil prices fell in mid-2014. UAE among other gulf countries has taken several steps to diversify, so as to protect itself as the oil prices continue to remain low. Although, several new policies and revenue streams have been developed, it may take a few years for any of them to yield results. The years 2015 and 2016 were the two years right after the fall and our results show that profitability and efficiency took a hit in these years. Although all profitability ratios plummeted in the post-fall period, the decrease in ROCE alone was statistically significant. ROCE is one of the most important profitability ratios and a decrease signals reduction in profits. Further insight into the ratio confirms fall in profits but another interesting element is revealed. It was seen that average liabilities steeply increased by $36 \%$. Such sharp increase in liabilities poses a 
severe warning sign and indicates economic distress. Lower profits and higher loans, both financial disasters point towards the slowdown in the economy post-fall in oil prices. The increase in loans was required and therefore expected due to the fall in earnings. The efficiency (receivable settlement) on the other hand was the other financial ratio that changed significantly. The number of days for which credit was extended reduced by more than three months. Although this is a positive development for the economy as such, in this context, it points towards lack of confidence in the market.

Liquidity, Gearing and Investment ratios remained unaffected in the post-fall period. The insurance industry is seen to be more liquid as the operating cashflows were higher in the post-fall period. This was an expected change given lower credit days. As earnings fell, more companies in the insurance industry took out long term loans to meet their financial commitments. Despite this, the gearing ratio changes are not significant. This points towards stability and the fact that the economy has diversified into the non-oil sectors as the fall in oil prices did not have a significant influence on gearing. It was rather interesting to study the changes in the Investment ratios - despite fall in earnings, higher dividends were paid to shareholders. This ensured that shareholders were happy and helped maintain a stable share price. Amidst lower oil prices, lower earnings and higher loans, the insurance industry overall made sure that the investor sentiment was never hurt.

The study confirms slowdown in the insurance industry with regards to profitability and efficiency, however, the liquidity, gearing and investment ratios stood strong in this period. It is worthwhile to note that the government and regulatory bodies have already taken action and adopted measures to put an end to the downfall. New policies ensure diversification from oil revenue and provides support for the economy to thrive in the absence of oil. Introduction of VAT (Value Added Tax) is one of the measures adopted to increase government revenue. The insurance industry has also put in place new regulations that make adoption of certain insurance products mandatory. This has a twosided effect - the amount of risk is reduced while the insurance sector prospers. Overall UAE has been mostly resilient to the fall in oil prices and given the visionary leadership of its policy makers, the diversification strategy has taken effect rather quickly.

While the study makes an attempt to understand the impact of fall in oil prices on the insurance industry, it is not without limitations. The study includes 31 companies listed on the stock exchanges, however, foreign and private unlisted companies that provide business locally are not included due to lack of data availability. This would not change our findings much, because these insurers represent a small percentage of the total industry. However, these foreign insurers are expected to further augment their presence in the gulf as they benefit from higher technical know-how, distribution capabilities, customer orientation and financial strengths. This could be one of the future avenues of 
study as such data becomes available. The study is also subject to inherent weaknesses of ratio analysis.

\section{References}

Adams, M \& Buckle, M (2003), The determinants of corporate financial performance in the Bermuda insurance market, Applied Financial Economics, vol. 13, no. 2, pp.133-143.

Al-Malkawi, H.N., Rafferty, M. and Pillai, R. (2010), "Dividend policy: a review of theories and empirical evidence", International Bulletin of Business Administration, Vol. 9, pp. 171-200.

Al-Shami, HAA (2008), Determinants of insurance companies' profitability in UAE, PhD diss., University Utara Malaysia, Malaysia.

Athanasoglou, PP, Sophocles, NB \& Matthaios, DD (2008), Bank-specific, industry-specific and macroeconomic determinants of bank profitability, Journal of International Financial Markets, Institutions and Money, vol. 18, no. 2, pp.121-136.

Basha, M. (2014), Impact of Increasing the Crude Oil Prices on the Financial Performance of Pharmaceutical Companies Operating in Jordan for the Period (2002-2011) A Case Study of Jordanian Al-Hikma Pharmaceutical Company. European Journal of Business and Management, 6(3), 150-156.

Berument, M. H., Ceylan, N. B., \& Dogan, N. (2010), The impact of oil price shocks on the economic growth of selected MENA countries. The Energy Journal, 149-176.

Beyer, S. (2010), International Corporate Finance - Impact of Financial Ratios on Long Term Credit Ratings: Using the Automotive Examples of BMW Group, Daimler Group and FordMotor Company, GRIN Verlag, Munich.

Burca, A \& Ghiorghe, B (2014), The determinants of financial performance in the Romanian insurance market, International Journal of Academic Research in Accounting, Finance and Management Sciences, vol. 4, no. 1, pp. 299-308.

Chen-Ying, $L$ (2014), The effects of firm specific factors and macroeconomics on profitability of propertyliability insurance industry in Taiwan, Asian Economic and Financial Review, vol. 4, no. 5, pp. 681.

Dayanandan, A., \& Donker, H. (2011), Oil prices and accounting profits of oil and gas companies. International Review of Financial Analysis, 20(5), 252-257.

Doğan, M (2013), Does firm size affect the firm profitability? Evidence from Turkey, Research Journal of Finance and Accounting, vol. 4, no. 4, pp. 53-59.

Dorsey, P. (2003), The Five Rules for Successful Stock Investing: Morningstar's Guide to Building Wealth and Winning in the Market, Wiley, Hoboken, NJ.

Downes, J. and Goodman, J.E. (2003), Barron's Finance \& Investment Handbook, Barrons Educational Series, Hauppauge, NY. 
El-Sharif, I., Brown, D., Burton, B., Nixon, B., \& Russell, A. (2005), Evidence on the nature and extent of the relationship between oil prices and equity values in the UK. Energy Economics, 27(6), 819-830.

Ernst and Young (2017), Insurance opportunities in the Middle East. Accessed on 18th April, 2018. Available at http://www.ey.com/Publication/vwLUAssets/ey-insurance-opportunities-in-the-middleeast/\$FILE/ey-insurance-opportunities-in-the-middle-east.pdf.

Ewing, B. T., \& Thompson, M. A. (2007), Dynamic cyclical co movements of oil prices with industrial production, consumer prices, unemployment, and stock prices. Energy Policy, 35(11), 5535-5540.

Gulf News (2017), Insurance sector in UAE projected to grow fastest in GCC in next five years. Accessed on 16th February, 2018. Available at: https://gulfnews.com/business/sectors/insurance/insurancesector-in-uae-projected-to-grow-fastest-in-gcc-in-next-five-years-1.2140437.

Kilian, L. (2008), Exogenous oil supply shocks: how big are they and how much do they matter for the US economy?. The Review of Economics and Statistics, 90(2), 216-240.

Lele, U. (2016), Impact of oil prices on revenue growth and profitability of Saudi listed companies in nonfinancial sectors. International Journal of Management, Information, Technology and Management and Engineering, 6(4), 13-20.

Malik, F., \& Ewing, B. T. (2009). Volatility transmission between oil prices and equity sector returns. International Review of Financial Analysis, 18(3), 95-100.

Malik, H (2011), Determinants of insurance companies profitability: Ananalysis of insurance sector of Pakistan, Academic Research International, vol. 1, no. 3, pp. 315.

Maghyereh, A., \& Al-Kandari, A. (2007), Oil prices and stock markets in GCC countries: new evidence from nonlinear co integration analysis. Managerial Finance, 33(7), 449-460.

Nandha, M., \& Faff, R. (2008), Does oil move equity prices? A global view. Energy Economics, 30(3), 986997.

Narayan, P. \& Sharma, S. (2011), New evidence on oil price and firm returns. Journal of Banking and Finance, 35, 3523-3262.

Omondi, MM \& Willy, M (2013), Factors affecting the financial performance of listed companies at the Nairobi Securities Exchange in Kenya, Research Journal of Finance and Accounting, vol. 4, no. 15, pp. 99-104.

Onaolapo, AA \& Sunday, OK (2010), Capital structure and firm performance: Evidence from Nigeria, European Journal of Economics, Finance and Administrative Sciences, vol. 25, pp. 70-82.

Organization of the Petroleum Exporting Countires (2018), OPEC share of world crude oil reserves. Accessed on 18th April, 2018. Available at: http://www.opec.org/opec_web/en/data_graphs/330.htm.

Sadorsky, P. (2008). Assessing the impact of oil prices on firms of different sizes: Its tough being in the middle. Energy Policy, 36(10), 3854-3861. 
Wattanatorn, W. \& Kanchanapoom, T. (2012), Oil Prices and Profitability Performance: Sector Analysis, Social and Behavioral Sciences, 40, \&63-767. 